九州大学学術情報リポジトリ

Kyushu University Institutional Repository

\title{
LAUXANIIDAE (DIPTERA) OF MALAYSIA (Part l)
}

Sasakawa, Mitsuhiro

Pong, Tho Yow

https://doi.org/10.5109/2535

出版情報 : ESAKIA. Special Issue 1, pp.123-136, 1990-04-20. Entomological Laboratory, Faculty of Agriculture, Kyushu University バージョン:

権利関係 : 


\title{
LAUXANIIDAE (DIPTERA) OF MALAYSIA (Part 1) ${ }^{*, \dagger}$
}

\author{
Mitsuhiro Sasakawa ${ }^{1}$ \\ Laboratory of Entomology, Faculty of Agriculture, Kyoto Prefectural University, \\ Shimogamo, Kyoto, 606 Japan \\ and \\ Thо Yow Pong \\ Forest Research Institute of Malaysia \\ Kepong, Selangor, Malaysia
}

\begin{abstract}
Four new species of Noonamyia abdominalis, euphlebia, sabahna and pleuralis, and Phobeticomyia bicolor n. sp. and Poecilomyza punctata n. sp. are described from Malaysia by the senior author, and eight species are new to the Malaysian fuana.
\end{abstract}

This is the first report of our study on the family Lauxaniidae of Malaysia based on the specimens collected by the senior author under the 1986 and 1988 joint Japanese-Malaysian projects of the "Systematic and Ecological Surveys on Some Plant-parasitic Microarthropods in Peninsular Malaysia and Sabah". Up to the present, sixteen species of lauxaniid-flies have been recorded fragmentary from Malaya by Walker (1856), Kertêsz (1900), Malloch (1927 \& 1929) and others. Six new species of the genera Noonamyia, Phobeticomyia and Poecilomyza are described in this paper. Judging from the results of our study, it may be considered that some more species of Noonamyia occur in the forests in Sabah. The dominancy of the genus, Homoneura van der Wulp, will be exhibited in the next paper.

Abbreviation : Names of bristles and setae are abbreviated as follows : acr, acrostichal ; dc, dorsocentral ; mpl, mesopleural ; oc, ocellar; or, fronto-orbital ; pa, postalar; prsc, prescutellar ; $p v t$, post-vertical ; sa, supra-alar ; sc, scutellar ; stpl, sternopleural.

Type depository : All the holotypes of new species are deposited in the collection of the Forest Research Institute of Malaysia (FRIM) and part of paratypes in the Kyoto Prefectural University.

\footnotetext{
* Scientific Results of Systematic and Ecological Surveys on Some Plant-parasitic Microarthropods in Southeast Asia, Report No. 7.

' Contribution No. 236 from Lab. Entom., Kyoto Pref. Univ.

${ }^{1}$ Present address: 7-6-7 Korigaoka, Hirakata City, Osaka Pref., 573 Japan.
} 


\section{Genus Sapromyza Fallen \\ Sapromyza (Sapromyza) quadrangulata (de Meijere)}

(Figs. 1-2)

Lauxania quadrangulata de Meijere, 1924, Tijdschr. Ent. $67: 48$.

Diagnosis. This whitish-gray pruinose, black species is distinct in having the brownish yellow dorso-proximal part on 3rd antennal segment, $0+2 \mathbf{d c}$, narrowly pruinose median and sublateral stripes and posterior margins, and broadly pruinose lateral margins on 3rd-5th abdominal tergites, and yellowish basal and apical rings on mid and hind tibiae. Wing length $\mathbf{2 . 3 - 2 . 5} \mathrm{mm}$.

Genitalia : Epandrium with surstylus long and broad, curved at end and minutelly serrated ; hypandrium expanded horizontally ; gonapophysis somewhat clavate ; aedeagus with lateral sclerites claw-like distally.

Specimens EXAmined. $10^{\top} 59 \%$, Kampung Moyog (350 m), nr. Kota Kinabalu, Sabah, Malaysia, 27. IX, 1988, M. Sasakawa ; 299, Sepilok, Sabah, 6. X. 1988, M. Sasakawa ;19, FRIM, Kepong, Selangor, 14. X. 1988, M. Sasakawa.

Distribution. Sumatra, Malaya, N. Borneo (Sabah), Philippines. New to Malaysia.

\section{Genus Trigonometopus Macquart}

This genus is cosmopolitan and peculiar in the shape of head, that is, subtriangular in profile.

\section{Trigonometopus (Trigonometopus) albiseta Bezzi}

Trigonometopus albiseta Bezzi, 1913, Philipp. J. Sci. (D) $8: 317$.

Diagnosis. This testaceous species is characterized by having whitish arista, wing with brown costal margin fused with three fasciae : two extending over both cross veins and a broad preapical one which leaves an apical hyaline lunule between apices of $R_{2+3}$ and $\mathrm{M}_{1+2}$, and brown apices of tibiae.

REMARKs. Brown oblique bands near outer bases of mid and hind femora are sometimes quite absent or only indistinctly on hind tibia.

Specimens eXamined. $10^{7}$, Kampung Moyog (350 m), nr. Kota Kinabalu, Sabah, Malaysia, 27. IX. 1988, M. Sasakawa ;29ᄋ, FRIM, Kepong, Selangor, Malaysia, 6 \& 21. VIII. 1986, M. Sasakawa.

Distribution. Philippines, Malaya, N. Borneo (Sabah), New to Malaysia.

\section{Trigonometopus (Trigonometopus) brunneicosta Malloch}

(Figs. 3-4)

Trigonometopus bmnneicosta Malloch, 1927, Ent. Mitt. $16: 165$.

This species was described by only one female specimen from Formosa. Male is similar to the female, but differs in the following points : Frons is about 1.5 times as long as wide, face is carinated distinctly on dorsal third; median vitta on the mesonotum and scutellum is separated into two vittae by a pale line between median rows of $a c r$, which are arranged in six rows anteriorly but four between levels of 1 st and 2 nd $\mathbf{d c}$ and only median rows extended entire length of notum ; wing is 3.4 $\mathrm{mm}$ long, with ultimate section of $\mathrm{M}_{1+2}$ is about twice as long as the penultimate ; abdominal tergites are fuscous on dorsal side and darkened along posterior margins but yellow broadly on lateral sides. Epandrium is provided with a pair of dark brown protuberances on postero-dorsal apex, surstylus is 


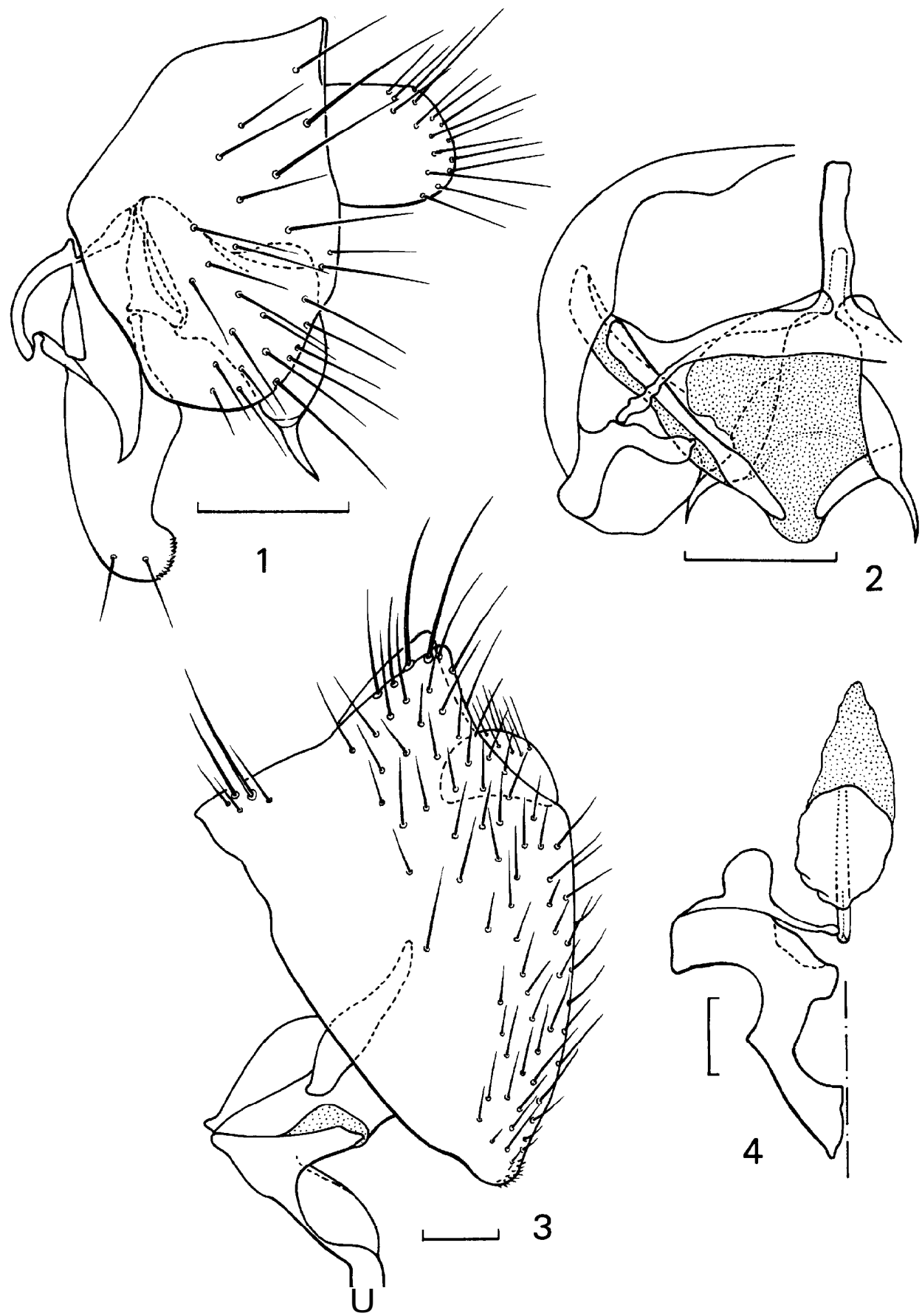

Figs. 1-4. Male genitalia of Sapromyza quadrangulata (de Meij.) 1, lateral view ; 2, ventral view. Male genitalia of Trigonometopus brunneicosta Mall. 3, lateral view ; 4, hypandrium and phallus, ventral view. Scale $0.1 \mathrm{~mm}$. 
small and tubercle-like ; hypandrium is V-shaped but separated at base ; aedeagus is only sclerotized basally.

Specimen eXAmined. lb, FRIM, Kepong, Selangor, Malaysia, 7. VIII. 1986, M. Sasakawa.

Distribution. Formosa, Malaya. New to Malaysia.

\section{Genus Trypetisoma Malloch}

The genus is distinguished from other genera by an extra bristle in addition to $m p l$ on the mesopleuron, $1+3 d c$ and bristle-like acr.

\section{KEY to SPECIES}

Abdomen glossy black; wing brown, 2.0-2.2 mm long, with three hyaline spots in cell $R_{1}$

- Abdomen testaceous to brownish, with gray-dusted spots at bases of marginal bristles ; wing brown, $2.3-2.5 \mathrm{~mm}$, with four spots in cell $\mathrm{R}_{1} \ldots \ldots \ldots \ldots \ldots \ldots \ldots$ tephritina (de Meijere)

2. Wing with three complete hyaline fasciae across the wing in addition to several spots sumatrana Malloch

- Wing without fasciae, but with three hyaline spots in cells $R_{1}$ and $R_{3}$, respectively fenestrata (de Meijere)

\section{Trypetisoma (Trypaneoides) fenestrata (de Meijere)}

Lauxania (Sapromyza) fenestrata de Meijere, 1910, Tijdschr. Ent. $53: 139$.

Wing with hyaline spots : three spots in cells $R_{1}$ and $R_{3}$, respectively ; two or three minute ones between large median and apical ones in cell $\mathrm{R}_{5}$, one large in discal cell, and others in posterior cells and at base of wing.

SPECIMENS EXAmined. $10^{7} 1$ \% , FRIM, Kepong, Selangor, Malaysia, 7. VIII. 1986, M. Sasakawa ; 10̛', Sepilok, Sabah, Malaysia, 6. X. 1988, M. Sasakawa.

Distribution. Java, Malaya, N. Borneo (Sabah), New to Malaysia.

\section{Trypetisoma (Trypaneoides) sumatrana Malloch}

Trypetisoma sumatrana Malloch, 1927, Suppl. Ent. 15: 105.

Diagnosis. This minute species is distinct in having three complete clear fasciae across the wing, the 1st one just proximad of inner cross vein, the 2 nd at about its own width beyond outer cross vein, the 3 rd extending across the wing from apex of vein $R_{2+3}$ in addition to a fasciform spot in cell $R_{1}$ extending slightly beyond vein $R_{2+3}$ between 1 st and 2 nd fasciae, and apical spot between apices of $R_{4+5}$ and $M_{1+2}$.

Discussion. Body coloration and chaetotaxy of this species are similar to those of fenestrata. Basal pair of SC is directed up- and inwards apically in all Malaysian species, but apical pair divergent in fenestrata and sumatrana, and parallel in tephritina. The extremely long marginal bristles on abdominal tergites are erect in all tergites of fenestrata and sumatrana, but only in the posterior three tergites in tephritina as well as in the species of Homoneura (Drosomyia).

Specimen eXAmined. 10̛', FRIM, Kepong, Selangor, Malaysia, 7. VIII. 1986, M. Sasakawa.

Distribution. Sumatra, Malaya. New to Malaysia. 


\section{Trypetisoma (Trypaneoides) tephritina (de Meijere)}

\section{Lauxaniatephritina de Meijere, 1914, Tijdschr. Ent. 57: 227.}

Diagnosis. This species is recognizable by the colorations of face (with a median brown band horizontally), mesonotum (brownish gray dusted, with small brown spots at bases of bristles), numerous hyaline spots on wing (four spots in cell $R_{1}$, four large and four small ones in cell $R_{3}$, six small ones in cell $\mathrm{R}_{5}$, etc.) and abdomen, and by having two extra bristles before $m p l$.

SPecimen eXamined. 10 , FRIM, Kepong, Selangor, Malaysia, 7. VIII. 1986, M. Sasakawa.

Distribution. Java, Sumatra, Philippines, Malaya, India. New to Malaysia.

\section{Genus Cestrotus Loew}

This genus is wide-spread in the Oriental, Ethiopian and Madagascar Regions. Stuckenberg (1971) made an attempt to group the known species by the presence or absence of setulae on the upper surface of radial veins. According to him, all Oriental species lack the setulae on whole veins and have a prominently humped frons.

\section{Cestrotus flavoscutellatus de Meijere}

Cestrotus flavoscutellatus de Meijere, 1910, Tijdschr. Ent. 53: 142.

Diagnosis. This species is distinct in having black- or brownish-spotted frons, face and gena, patterned wings, yellow scutellum except base brown, and brown basal and apical rings on all yellow tibiae.

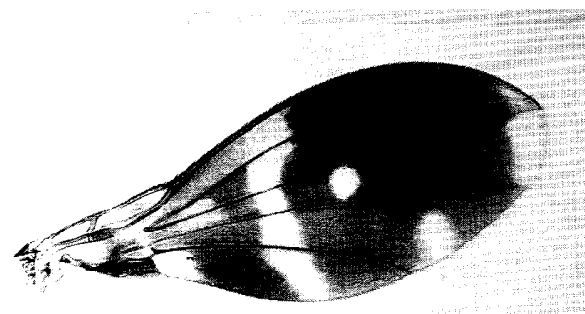

A

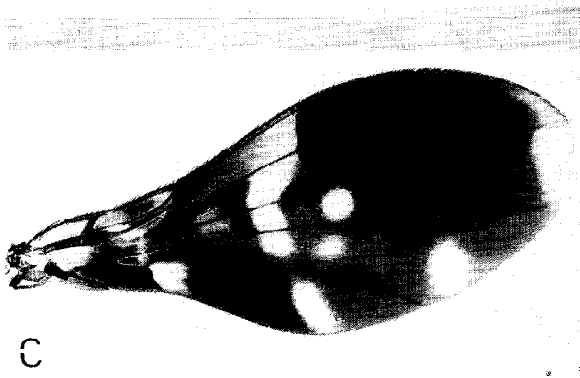

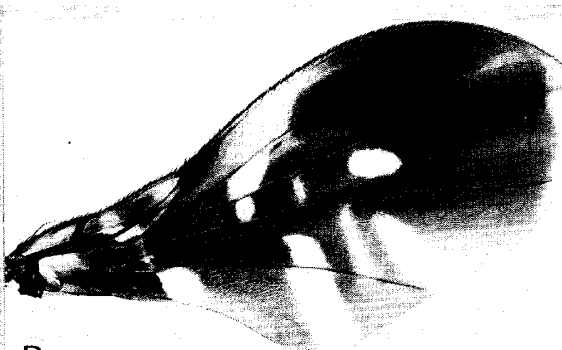

B

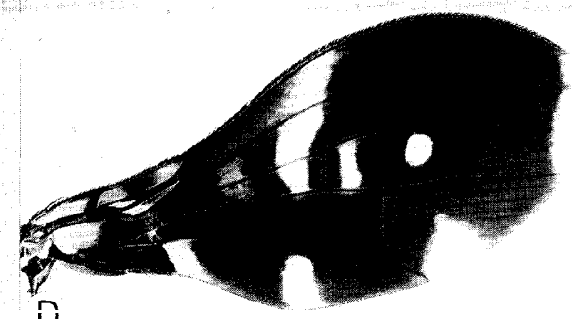

Figs. 5 (A-D). Wings of Noonamyia abdominalis Sasakawa n. sp. (A), N. euphlebia Sasak. n. sp. (B), N. sabahna Sasak. n. sp. (C) and N. pleuralis Sasak. n. sp. (D). 


$$
\mid \begin{array}{ll}
0 \\
0
\end{array}
$$


Specimen examined. 19, Kampung Moyog $(350 \mathrm{~m})$, nr. Kota Kinabalu, Sabah, Malaysia, 27. IX. 1988, M. Sasakawa.

Distributron . Formosa, Java, N. Borneo (Sabah), Nepal. New to Malaysia.
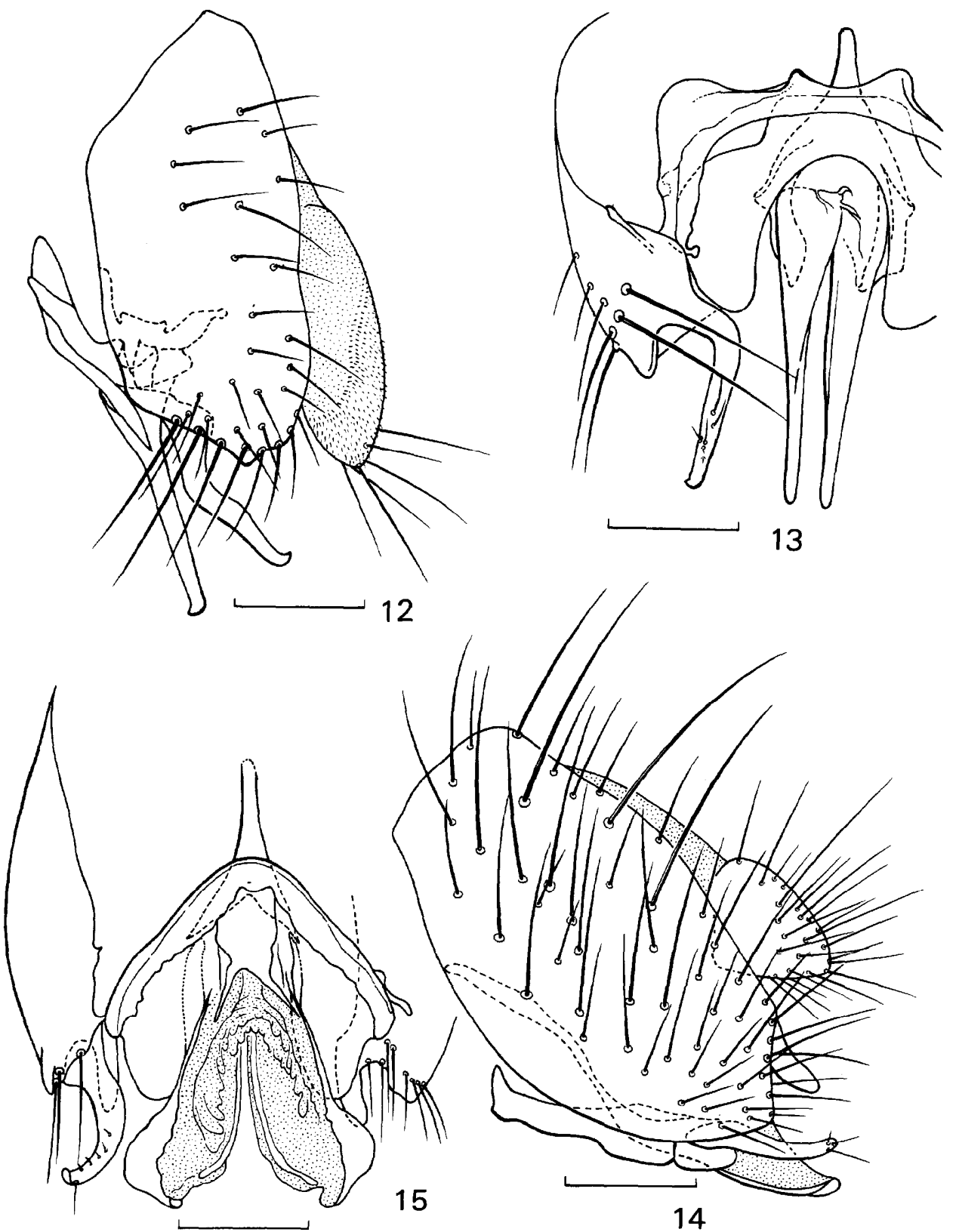

Figs. 12-15. Male genitalia of Phobeticomyia bicolor Sasakawa n. sp. (12-13) and P.lunifera (de Meij.) (14-15). See Figs. 1-2. 


\section{Genus N oonamyia Stuckenberg}

This Oriental genus was established by Stuckenberg (1971) for two species, palawanensis and lyneborgi from the Philippines by the nature of antennae, fronto-orbital bristles and wing. Two more Philippine species, Neogeomyza irregularis Frey and fascipennis Frey, were transfered to this genus by Shewell (1977). Four further species were collected by the senior author in the forests of the Peninsula and Sabah, Malaysia, and described below as new to science. They present a quite different appearance in their wing pattern.

\section{KEY TO SPECIES}

1. Wing with a complete hyaline fascia across the wing just basad of cross vein $\mathrm{r}-\mathrm{m} \ldots \ldots \ldots \ldots . . \ldots 2$

- Wing without a complete fascia basad of $\mathrm{r}-\mathrm{m}$

2. Wing with 1 or 2 circular spots in cell $R_{5}$ (1st posterior cell) in addition to apical spot ; mesonotum with 6 rows of acr setae ; abdominal tergite $1+2$ testaceous to yellowish brown

- Wing without spots but with a fascia laterad of cross veins, extending from vein $\mathrm{R}_{2+3}$ to posterior wing margin ; 8 rows of acr; abdominal tergites entirely black '. fascipennis (Frey)

3. Wing with 2 hyaline spots in cell $R_{5}$; sternopleuron whitish yellow; fore tibia without dorsal preapical bristle ; surstylus represented merely by a single tooth ventrally

lyneborgi Stuckenberg

Wing with a spot in cell $\mathrm{R}_{5}$; stemopleuron brownish black ; fore tibial preapical present but short ; epandrium with a pair of distinct processes caudad of striated surstyli

abdominalis $\mathrm{n} . \mathrm{sp}$

4. Wing with a hyaline spot in discal cell and hyaline fascia before $\mathrm{r}-\mathrm{m}$ incomplete, interrupted at vein $\mathrm{M}_{3+4}$ sabahna n. sp.

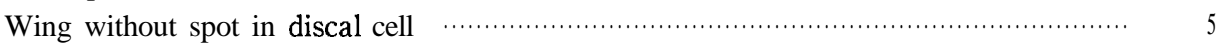

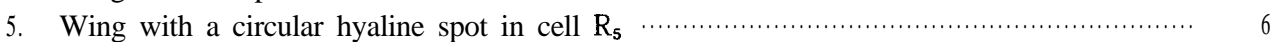

- Wing without spot but with 3 short fasciae basad of $\mathrm{r}-\mathrm{m}$ (extending from costa to $\mathrm{M}_{3+4}$ ), between both cross veins $\left(R_{2+3}\right.$ to posterior margin of wing) and outside of $m-m\left(R_{4+5}\right.$ to

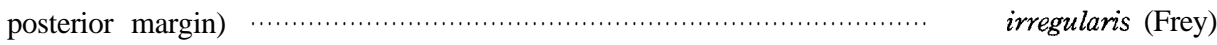

6. Hind tibia with a short preapical bristle dorsally; wing with narrow hyaline stripes around both cross veins in addition to short fasciae and spots euphlebia $\mathrm{n} . \mathrm{sp}$. Hind tibia without preapical ; cross veins enclosed by brown

7. Pleura yellowish, with a horizontal brown stripe extending caudad from propleuron; wing with hyaline fascia before $r-m$ connected with the one in cell $R_{5}$ just caudad of vein

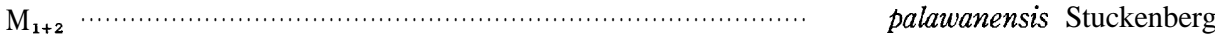

Pleura blackish brown, sternopleuron yellow except dorsal margin ; wing with fasciae isolated beside $\mathrm{r}-\mathrm{m}$

pleuralis n. sp.

Noonamyia abdominalis Sasakawa, n. sp. (Figs. 5A, 6, 7)

Diagnosis. This new species is related to lyneborgi Stuckenberg in the wing pattern, but has only one circular spot in cell $\mathrm{R}_{5}$ and a dorsal preapical bristle on fore tibia. Males have a pair of distinct 
processes caudad of surstyli as in palawanensis Stuckenberg.

Description. Head with frons testaceous, shining, sparsely whitish pollinose; dorsal half of occiput brown ; face pale brown, subshining, whitish dusted ; parafacialia, gena, postgena and palpus yellow ; antenna pale testaceous, 3rd segment more or less darkened apically, arista brown. Thorax shining black, mesonotum and pleura densely whitish 'dusted, the latter tinged with brown, hypopleuron pale brown. Wing brown, with a hyaline fascia across the wing just basad of cross vein $r-m$ and spot in cells $R_{5}$ and $M_{2}$, respectively ; halter yellowish, with knob slightly infuscated. Legs yellow, apices of mid and hind femora, basal half (0) to almost whole length (९) of mid tibia brownish, distal two segments of tarsi faintly infuscated. Abdomen shiny black, but anterior two tergites, anterior margin of 3rd tergite and dorsal side of 6th tergite testaceous to yellowish brown, the latter darkened laterally, protandrium and epandrium yellow ; stemites testaceous yellow ; ovipositor yellow.

Frons nearly twice as wide as long, 1.5-1.7 times as wide as eye ; parafrontalia with posterior or about $1 / 3$ length of the anterior ; oc about $2 / 3$ length of anterior $o r$; pvt inclinate and usually not crossed distally ; face almost flat, not projecting before parafacialia in profile except for ventral end ; eye about 1.2 times as high as broad ; gena linear ; antenna with 3rd segment inclined outward at about 45" to longitudinal body axis, 2nd segment with two or three long ventral bristles, outer longest one almost extending ventrally beyond epistomal margin, 3rd segment twice as long as wide, narrowing apically, distinctly pilose; arista plumose, with longest hair twice width of 3rd segment.

Mesonotum with $0+3 \mathbf{d c}$, $1 \mathrm{st} \mathbf{d c}$ at suture, 6 rows of $a \mathrm{cr}$, ending just behind level of $2 \mathrm{nd} \mathrm{dc}, \mathbf{p m}$ absent, outer pa weak, inner $p a 1 / 3-1 / 5$ length of the outer ; anterior stpl $1 / 2-2 / 3$ of the posterior. Wing with ultimate section of $\mathrm{M}_{1+2}$ 2.3-2.5 (o ) to 2.5-2.7 (₹) times as long as the penultimate; ultimate section of $\mathrm{M}_{3+4}$ about $1 / 5$ of penultimate ; cross vein $\mathrm{m}-\mathrm{m}$ distinctly oblique, forming an angle of 60 " at posterior corner. Fore femur with antero-ventral comb of minute spines on apical half and one long postero-ventral bristle just before middle of femur; fore tibia with a very short preapical bristle dorsally ; hind tibia without preapical ; mid tibia with one exceptionally long spur and minute one.

Genitalia: Epandrium deeply incised on each latero-ventral 1/3, producing a narrow process posteriorly and a broad, striated surstylus anteriorly ; hypandrium W-shaped ; gonapophysis small, bearing a seta; aedeagus with lateral sclerites narrow in lateral view, hooked at apices.

Body length 2.3-2.5 (holotype) $\mathrm{mm}$; wing length 2.4-2.5 (holotype) $\mathrm{mm}$ in males, $2.6-3.0 \mathrm{~mm}$ in females.

Holotype 6, Sepilok, Sabah, Malaysia, 7. X. 1988, M. Sasakawa. Paratypes 4ơ ơ ,5 data as holotype.

Distributron. Malaysia (Sabah).

\section{Noonamyia euphlebia Sasakawa, n. sp.}

(Fig. 5B)

Diagnosis. This species is unique by having a dorsal preapical bristle on hind tibia and two hyaline stripes around both cross veins in addition to other fasciae and spots.

Description. Head yellow, but frontalia pale brown, ocellar triangle darkened, parafrontalia and dorsal half of occiput testaceous; face and parafacialia silvery pruinose ; area between lower parafacialia and peristomal margin shining brown ; antenna with 1st and 2nd segments yellowish to pale brown, 3rd segment with outer ventral $1 / 2-3 / 4$ and apex brown except base testaceous yellow but not infuscated on inner apex, arista black but yellow at base ; palpus dark brown to black. Thorax strongly shining brownish black, but more or less paler on anterior declivity of notum and 
scutellum, mesonotum and scutellum very sparsely and pleura densely whitish gray dusted. Wing brown, with three hyaline fasciae anteriorly and posteriorly, narrow fasciae around both cross veins and a spot in cell $R_{5}$; halter yellow, with knob brown except dorsal side. Legs testaceous, fore femur darker ; mid and hind legs with coxae, trochanters and femora whitish yellow, apical $1 / 4$ of femora and tibiae entirely brown. Abdomen shining black but posterior two tergites testaceous, sparsely pollinose on anterior four tergites.

Frons about twice as wide as long, 1.3-1.5 times as wide as eye, almost parallel-sided ; parafrontalia with posterior or $2 / 3$ length of the anterior; oc slightly longer than posterior $o r$; face slightly raised centrally, sometimes weakly carinated on dorsal $2 / 3$, projecting beyond parafacialia in profile ; eye 1.2-1.4 times as high as broad ; gena narrow, 1/9-1/11 height of eye ; antenna with 3rd segment inclined outward at about 45 " to longitudinal body axis; 2nd segment with two long ventral bristles, outer one longer than length of 3rd segment and extending ventrally to or beyond epistomal margin, 3rd segment 2.5 times as long as wide, gradually narrowing apically; arista plumose, with longest hair twice width of 3rd segment.

Mesonotum with $0+3 d c$, 1st $d c$ on suture ; acr in 6 rows, ending just behind level of 2nd $d c$, prsc absent, outer $p a$ weak, less than $1 / 2$ length of $s a$, inner pa $1 / 3$ length of the outer ; anterior $s t p l 1 / 3$ $1 / 2$ of the posterior. Wing with ultimate section of $\mathrm{M}_{1+2}$ about six times as long as the penultimate, ultimate section of $\mathrm{M}_{3+4}$ nearly $1 / 3$ of penultimate. Fore femur with antero-ventral comb of minute spines on about apical $1 / 3$ to $1 / 2$ and two long postero-ventral preapical bristles ; fore and hind tibiae each with a dorsal preapical bristle but weak, mid tibia with one exceptionally long spur and minute one.

Body length 2.5-2.7 (holotype) mm, wing length 3.0-3.2 (holotype) $\mathrm{mm}$.

Male unknown.

HolotyPe + , Pasoh Forest Reserve, Negeri Sembilan, West Malaysia, 9-13. VIII. 1986, M. Sasakawa. Paratypes 19, FRIM, Kepong, Selangor, Malaysia, 7. VIII. 1986, M. Sasakawa; 19, Kampung Moyog (350 m), nr. Kota Kinabalu, Sabah, Malaysia, 27. IX. 1988. M. Sasakawa.

Distribution. Malaysia (Selangor, Negeri Sembilan, Sabah).

\section{Noonamyia sabahna Sasakawa, n. sp.} (Figs. 5C, 8, 9)

Diagnosis. This species is recognized without trouble by its specially fasciate and spotted wings, and short epandrial processes projected ventrally.

Description. Closely related to abdominalis n. sp., but the head testaceous ; frontalia with a pair of brown lateral triangles extending from its lateral margins to middle line and connected with each other at middle; parafrontalia brown ventrad of posterior or which is about $1 / 2$ length of the anterior; pvt barely crossed at apices; face brown in ground color ; thorax shining black, dusted with brownish gray ; wing $2.8 \mathrm{~mm}$ long, dark brown, with fascia basad of $\mathrm{r}-\mathrm{m}$ interrupted on vein $\mathrm{M}_{3+4}$, and a spot in discal cell, ultimate section of $\mathrm{M}_{1+2} 2.6$ times as long as the penultimate, cross vein $\mathrm{m}-\mathrm{m}$ almost straight, forming an angle of 75 " at posterior corner ; apices of mid and hind femora and basal half of mid tibia distinctly infuscated ; 6th abdominal tergite entirely brownish black.

Genitalia : Epandrium with posterior process short, about $1 / 5$ height of epandrium ; surstylus striate and setose ; hypandrium membranous centrally, with side pieces sclerotized narrowly ; gonapophysis with seta kneed.

Body length $2.8 \mathrm{~mm}$.

Female unknown.

HoLOTYPE ơ, Kampung Moyog (350 m), nr. Kota Kinabalu, Sabah, Malaysia, 27. IX. 1988, M. 
Sasakawa ; right wing and genitalia mounted on a slide.

Distribution. Malaysia (Sabah).

\section{Noonamyia pleuralis Sasakawa, n. sp.}

(Figs. 5D, 10, 11)

Diagnosis. The wing pattern and coloration of sternopleuron of pleuralis are somewhat similar to those of palawanensis Stuckenberg and lyneborgi Stuckenberg, respectively. However, this species differs from them in the characters given in the key above.

Description. Differs from euphlebia n. sp. in the following points: Parafrontalia darker than frontalia, face pale brown in ground color, brown angle of epistoma indistinct ; 3rd antenna1 segment infuscated excepting base narrowly and especially darkened antero-ventrally ; palpus testaceous ; thorax densely whitish gray dusted, especially on lateral sides of mesonotum and pleura, sternopleuron yellow except dorsal margin pale brown; abdomen black; wing dark brown, with one hyaline fascia and one circular spot in cell $R_{5}$, posterior spots smaller, and without fasciae on cross veins ; mid and hind femora brown on apical $1 / 2$ to $3 / 4$.

Parafrontalia with posterior or $1 / 5-2 / 3$ length of the anterior, rarely absent ; pvt inclinate but not decussate ; face with a median carina low and indistinct, slightly beyond parafacialia in profile ; 1st dc behind suture ; two $s t p l$ subequal in length ; ultimate section of $\mathrm{M}_{1+2}$ rather distinctly curved anteriorly on basal $1 / 3$ and 3.0-3.6 times as long as the penultimate, ultimate section of $\mathbf{M}_{3+4}$ nearly $1 / 4$ length of penultimate ; fore femur with one postero-ventral preapical bristle, hind tibia without preapical.

Eighth and 9th sternite similar to each other in size, rectangular, 10th stemite somewhat pentangular ; spermathecae four in number, orbicular, 60-63 $\mu \mathrm{m}$ in diameter. Body length $2.8 \mathrm{~mm}$, wing length 2.6 (holotype) $-3.0 \mathrm{~mm}$.

Male unknown.

HolotyPE Q, Sepilok, Sabah, Malaysia, 7. X. 1988, M. Sasakawa. Paratypes 2 \%q, same data as holotype.

Distribution. Malaysia (Sabah).

\section{Genus Phobeticomyia Kertész}

The genus is readily recognized by a glossy bulbosity on face. Only three species have been recorded from the Philippines, Malaya and Borneo.

Phobeticomyia bicolor Sasakawa, n. sp.

(Figs. 12, 13)

Diagnosis. This species exhibits the sexual dimorphism, that is, facial bulbosity bicolored in male and enirely black in female. It differs from P. lunifera (de Meijere) and punctata (Walker) in having a narrow hyaline fascia preapically in the cell $\mathrm{M}_{2}$ (2nd posterior cell) in addition to each one hyaline spot on outer cross vein and ultimate section of $\mathrm{M}_{3+4}$.

Description. Head with frons testaceous to pale brown, ocellar triangle and occiput brownish black, sparsely grayish dusted ; parafrontalia surrounded by black stripes on inner and outer sides ; face in male brown on dorsal half including dorsal $1 / 3$ of bulbosity which is yellow ventrally but weakly infuscated in a form of $\mathrm{V}$ just above epistoma, while in female entirely glossy black ; parafacialia black on dorsal half, with a yellowish triangle laterad of antennal base, and yellow 
ventrally ; gena, peristomal margin and ventral part of postgena yellow, whitish pruinose ; antenna orangish, 3rd segment brownish black on apical half in female but only with a dark spot (about $1 / 2$ as long as whole length of segment) in male at middle of dorsal margin ; proboscis and palpus brown. Thorax black; mesonotum, pleura and scutellum densely brownish gray dusted in male excepting ventral margin of mesopleuron strongly shining, pleura in female densely whitish gray dusted excepting notopleuron sparsely ; mesonotum in female with a pair of brown-pollinose stripes (each bifurcated at level of $1 \mathrm{st} \mathrm{dc}$, extended postriorly along inner side of dc-line and midway between $d c$ and sa-lines and ended at middle between levels of 2nd and 3rd dc). Wing brown, with a hyaline fascia at extreme apex, two hyaline spots in cells $R_{3}$ and $R_{5}$, respectively, subquadrate or subcircular in female but narrow as horizontal line in male ; calypter whitish, with margin yellow and fringe pale brown; halter yellow. Legs with coxae, trochanters and femora brown but femora in female distinctly darkened, tibiae and tarsi yellow, the former with brown apical and median rings. Abdomen black, subshining, sparsely brownish dusted.

Frons twice as wide as long, about 1.5 times as wide as eye, slightly diverging ventrally ; posterior or about 1.5 times as long as anterior or ; oc subequal to anterior or in length ; facial bulbosity extending distinctly beyond parafacialia in profile ; gena narrow, about $1 / 8$ height of eye, six setulae from peristoma to parafacialia ; antenna with 3rd segment inclined outward at about 45" to longitudinal body axis as in species of Noonamyia, twice as long as wide, narrowing apically ; arista plumose, with dorsal longest hair 1.5 times width of 3rd segment but ventral one shorter than width of 3rd segment.

Mesonotum with $0+3 \mathbf{d c}, 1$ st $\mathbf{d c}$ behind suture, acr in 8 rows anteriorly but 6 behind level of 1 st dc, prsc shorter than 1 st dc, both pa strong; anterior stpl slightly shorter than the posterior. Wing with 2nd costal section 2.7 times as long as the 3rd, r-m slightly beyond middle of discal cell, ultimate section of $\mathrm{M}_{1+2}$ about 1.7 times as long as the penultimate, ultimate section of $\mathrm{M}_{3+4}$ about $1 / 5$ of penultimate.

Protandrium about $1 / 4$ length of 6 th tergite, distinctly narrowing ventrally ; 4-6th sternites oblong, each slightly longer than wide, with a median pair of posterior setae extremely long. Genitalia : Epandrium with setae short except ventral ones, slightly projected postero-ventrally, surstylus long but narrow; aedeagus with lateral sclerites narrow.

Body length $3.6 \mathrm{~mm}$, wing length 2.7 (\%) $-2.8\left(0^{7}\right) \mathrm{mm}$.

Holotype , Sepilok, Sabah, Malaysia, 7. X. 1988, M. Sasakawa. Paratype ơ, same data as holotype.

Distribution . Malaysia (Sabah).

Discussion. In the note to Noonamyia Stuckenberg (1971) made a point of the markedly diverging third antennal segment as one of the generic characters. However, this occurs also in the species of Phobeticomyia described above and the following. Species of Noonamyia has the very long, somewhat crooked ventral bristles on the second antennal segment, while in the species of Phobeticomyia those are approximately equal to or shorter than length of the third segment and not crooked.

\section{Phobeticomyia Iunifera (de Meijere)}

(Figs. 14, 15)

Lauxanialunifera de Meijere, 1910, Tijdschr. Ent. $53: 134$.

Diagnosis. This species is characterized by having a broad V-shaped yellow marking on black facial bulbosity, an apical hyaline fascia and many hyaline spots on brown wings and all tibiae with preapical rings yellow. Wing $2.9 \mathrm{~mm}$ long in male and $2.5 \mathrm{~mm}$ in female. 
Genitalia : Epandrium densely setigerous, with a pair of short processes above postero-ventral corners, surstylus narrow and distinctly curved ; aedeagus with lateral lobes expanded posterolaterally.

Specimens eXAmined. 10 19\%, Sepilok, Sabah, Malaysia, 6. X. 1988, M. Sasakawa.

Distribution. Java, Philippines, N. Borneo (Sabah), India, Ceylon, Nepal. New to Malaysia (Sabah).

\section{Genus Poecilomyza Malloch}

Poecilomyza was established as a subgenus of Homoneura van der Wulp, 1891, type-species: Phobeticomyia boettcheri Frey, 1927, which is not provided with the hind tibial preapical bristle dorsally, by Malloch (1929). Shewell (1977) erected this taxon as a distinct genus. The nature of the laterally compressed fore tibia in male of boettcheri and setulose scutellum in female of punctata $\mathrm{n}$. sp. is sufficient for generic separation.

\section{Poecilomyza punctata Sasakawa, n. sp.}

Diagnosis. This large, testaceous species can be easily separated from the small, black boettcheri (Frey) known from the Philippines.

Description. Pale testaceous but occiput, epistoma, palpus, pleura and postnotum yellow ; frons with a pair of brown stripes inside of parafrontalia, whitish pruinose ; face shining yellowish brown, sparsely pollinose ; parafacialia silvery pruinose on ventral part; arista brown except base. Mesonotum shiny, very sparsely dusted, mesopleuron shining. Wing faintly tinged with yellow, with large clouds on apex of $R_{2+3}$ and before apices of $R_{4+5}$ and $M_{1+2}$, round spot on cross vein $r-m$ and fascia on cross vein $\mathrm{m}-\mathrm{m}$; apical cloud on $\mathrm{R}_{2+3}$ beginning at level of outer cross vein connected with the one remote from apex of $R_{4+5}$, preapical cloud on $M_{1+2}$ about $3 / 4$ as long as the one on $R_{4+5}$ and connected obscurely with each other, spot on $\mathrm{r}-\mathrm{m}$ not covered anterior fork of vein ; halter yellow. Legs yellow, tibiae and tarsi faintly infuscated. Abdomen with 3rd-5th tergites darkened anteriorly.

Head higher than width $(13: 9)$; frons slightly wider than long or width of eye, with several minute hairs scattered on ventral part ; oc subequal to anterior or in length ; parafrontalia with anterior or $2 / 3$ length of the posterior, orbital hairs minute but distinctly in a row below level of posterior or ; face convex vertically at middle, distinctly beyond parafacialia in profile ; eye higher than broad $(10: 8)$; gena $1 / 8$ height of eye ; posteromost peristomal seta and ventromost postgenal seta extremely long. Antenna with longest ventral bristle on 2nd segment almost reaching apex of 3rd segment ; 3rd segment about twice as long as wide, slightly narrowing apically; arista plumose, with longest hair nearly twice width of 3rd segment.

Mesonotum with $0+3 d c, 12$ rows of acr setae, prsc strong; scutellum with 5 irregular rows of setulae on each dorso-lateral side ; stpl two, anterior one slightly shorter than the posterior. Wing with 2nd costal section about 3.3 times as long as the 3rd ; r-m before middle of discal cell ; ultimate section of $\mathrm{M}_{1+2}$ slightly longer than the penultimate, ultimate section of $\mathrm{M}_{3+4} 1 / 8-1 / 9$ length of penultimate. Fore femur with antero-ventral comb of minute spines ; fore tibia normal ; mid tibia with a row of ten strong bristles on postero-dorsal surface and three spurs ventrally; hind tibia without dorsal preapical briste.

Body length $5.5 \mathrm{~mm}$, wing length $4.6 \mathrm{~mm}$.

Male unknown.

HolotyPe 9 , Kampung Moyog (350 m), nr. Kota Kinabalu, Sabah, Malaysia, 27. IX. 1988, M. Sasakawa. 
Distribution. Malaysia (Sabah).

\section{Acknowledgements}

We wish to express our thanks to the project members, Drs. H. Mori, S. Takagi, T. Kumata and Y. Saito of Hokkaido University, Sapporo, Dr. S. Ehara of Tottori University, Tottori, and Dr. S. G. Khoo of University of Malaysia, Kuala Lumpur, and to Dr. Y. Yoshiyasu of Kyoto Prefectural University, Kyoto, for his help in many ways and Dr. T. Hirowatari of University of Osaka Prefecture, Sakai, for literature.

\section{R eferences}

Bezzi, M., 1913. Studies in Philippine Diptera I. Philip. J. Sci., (D) $8:$ 305-332.

Frey, R., 1927. Philippinische Dipteren IV. Fam. Lauxaniidae. Acta Soc. Fauna Flora fem., 56(8): $l-44$.

— 1958. Studien tiber ostasiatische Dipteren VI. Nothybidae, Micropezidae, Opomyzidae. Notul. ent., 38: 37-51.

Kertész, K., 1900. Beiträge zur Kenntniss der Indo-Australischen Sapromyza-Arten. Természetr. Füz., $23:$ 254-276.

- 1915. H. Sauter's Formosa-Ausbeute. Lauxaniinae II. Annlshist.-nat.Mus.natn. hung., 13 : 491-534.

Malloch, J. R., 1927a. Fauna sumatrensis (Beitrag Nr. 40). Sapromyzidae (Diptera). Supplta ent., 15: $102-110$.

— 1927b. H. Sauter's Formosa collection : Sapromyzidae (Dipt.). Ent.Mitt., 16 : 159-172.

— 1929. Notes on some Oriental sapromyzid flies (Diptera), with particular reference to the Philippine species. Proc.U.S.natn. Mus., 74(6) : 1-97.

— 1935. Exotic Muscaridae (Diptera) XXXIX. Ann. Mag. nat. Hist., 10(16) : 217-240.

Meijere, J. C. H. de, 1910. Studien tiber stidostasiatische Dipteren IV. Die neue Dipterenfauna von Krakatau. Tijdschr. Ent., 53: 58-194.

— 1914. Studien tiber stidostasiatische Dipteren IX. Ibid., 57 : 137-276.

- 1924. Studien tiber stidostasiatische Dipteren XV. Dritter Beitrag zur Kenntnis der sumatranischen Dipteren. Ibid., 67 (Suppl.) : 1-87.

Shewell, G. E., 1977. Superfamily Lauxanioidea, Family Lauxaniidae. In A catalog of the Diptera of the Oriental Region Vol. III, pp. 182-214. (Univ. Press Hawaii)

Stuckenberg, B. R., 1971. A review of the Old World genera of Lauxaniidae (Diptera). Ann. Natal Mm., 20(3) : 499-610.

Walker, F., 1856a. Catalogue of the dipterous insects collected at Singapore and Malacca by Mr. A. R. Wallace, with descriptions of new species. J.Proc.Linn.Soc. Lond., Zool., 1: 4-39.

1856b. Catalogue of the dipterous insects collected at Sarawak, Borneo, by Mr. A. R. Wallace. Ibid., $1:$ 105-136. 